\title{
Seasonal variation in total phenolic content of Dictyopteris polypo- dioides (Dictyotaceae) and Cystoseira amentacea (Sargassaceae) from the Sicilian coast*
}

\begin{abstract}
Mannino, A.M., Vaglica, V. \& Oddo, E: Seasonal variation in total phenolic content of Dictyopteris polypodioides (Dictyotaceae) and Cystoseira amentacea (Sargassaceae) from the Sicilian coast. — Fl. Medit. 24: 39-50. 2014. — ISSN: 1120-4052 printed, 2240-4538 online.

This study focuses on the differences in total phenolic content and its seasonal variations in two temperate brown algae, Cystoseira amentacea (C. Agardh) Bory and Dictyopteris polypodioides (A.P. De Candolle) J.V. Lamouroux, inhabiting respectively the infralittoral fringe and the upper infralittoral zone.

Phenolic compounds are secondary metabolites, found in almost all brown algal orders, that function as defense against grazers, epiphytes and UV radiation. Total phenolic content was determined colorimetrically with the Folin-Ciocalteu reagent. Results showed significant differences in total phenol content between D. polypodioides and C. amentacea with higher values observed in the first one. Differences in the seasonal pattern of total phenolic content and in the period of maximum production were also observed between the two species. The observed differences could result from differences in morphology, life-cycle and bathymetric level.
\end{abstract}

Key words: Brown algae, Mediterranean Sea, phenols, secondary metabolites, temporal variations.

\section{Introduction}

In response to variations of abiotic and biotic factors, seaweeds may produce and accumulate large quantities of secondary metabolites that function as defence compounds (Lüning 1990; Lobban \& Harrison 1994; Amsler 2008; Paul \& al. 2011; Sudatti \& al. 2011). Polyphenols are secondary metabolites commonly found in macroalgae but also present in higher plants (Arnold \& al. 1995; Tahi \& al. 2008; Al-sane \& al. 2011; Kremer $\&$ al. 2012; Martinelli \& Tonutti 2012). Brown algae (Phaeophyceae) present a high content of phenols, mainly phlorotannins (Ragan \& Glombitza 1986; Targett \& al. 1995), that can be stored in special vesicles (physodes) within the cells (Ragan \& Glombitza 1986; Pavia \& al. 1997; Van Alstyne \& al. 1999) or can be involved in cell-wall hardening (Schoenwaelder \& Wiencke 2000; Koivikko \& al. 2005). Dictyotales and Fucales are par-

* Extended and enriched version of the poster presented at the XIV Optima meeting in Palermo, 915 Sept. 2013. 
ticularly rich in these compounds that may constitute up to $30 \%$ of the dry weight (Ragan \& Glombitza 1986; Targett \& al. 1995; Targett \& Arnold 2001; Lee 2008).

These molecules, that certainly result in a cost to the algae, such as increased metabolic demand and decreased growth rates (Hay \& Fenical 1988; Steinberg 1995), function as defence against grazers, pathogens and epiphytes (Conover \& Sieburth 1964; Van Alstyne \& Paul 1990; Amsler \& Fairhead 2006), and as protection against solar radiation, especially UV radiation (Pavia \& al. 1997). Phlorotannins concentration can vary within and among species, being affected by seaweed size, age, tissue type, environmental or biotic factors, and can also have spatial variations (Ragan \& Glombitza 1986; Van Alstyne \& al. 2001; Amsler \& Fairhead 2006; Jormalainen \& Honkanen 2008; Lopes \& al. 2012). These compounds can also vary throughout the year (Ragan \& Jensen 1978) and their seasonal variations are species specific (Connan 2004).

The Mediterranean Sea is essentially a tideless sea, therefore sea water level varies more as a result of changes in barometric pressure and local wave exposure (Feldmann 1937; Ballesteros \& Romero 1988). Seaweeds living in the infralittoral fringe, encountering regular emersion as a result of wave movements, experience harsher environmental stress conditions (e.g. partial desiccation and higher irradiances) than those inhabiting the infralittoral zone that are constantly submerged. To cope with stress conditions, these algae also produce chemical compounds such as phlorotannins (Hay 1996; Potin $\&$ al. 2002; Amsler 2008). Moreover, it has been observed that phenolic content may vary in relation to bathymetric gradients, thallus structure and morphology, and ontogenetic stages (Tuomi \& al. 1989; Peckol \& al. 1996; Pavia \& Brock 2000; Henry \& Van Alstyne 2004; Stiger \& al. 2004; Le Lann \& al. 2012). For example, it has been observed in Fucus vesiculosus Linnaeus that phenols accumulated mainly in vegetative parts of the thallus having lower toughness, such as the apical parts, in order to better protect them from herbivores (Tuomi \& al. 1989).

Our aim was to investigate the relationship among thallus morphology, ontogenetic stages and zonation, and the phenolic content of two brown algae, Cystoseira amentacea (C. Agardh) Bory (Sargassaceae), a leathery alga living in the infralittoral fringe and Dictyopteris polypodioides (A.P. De Candolle) J.V. Lamouroux (Dictyotaceae), a sheet alga living in the upper infralittoral zone. We also followed the seasonal changes in the phenolic content in these two species.

\section{Materials and methods}

\section{Study area and sampling}

Samples were collected in the year 2012 within the Marine Protected Area (MPA) Capo Gallo-Isola delle Femmine, located along the north-western coast of Sicily (NW Mediterranean Sea; N 38¹2’35"; E13¹7’06”; Fig. 1).

Thalli $(\mathrm{n}=5)$ of $C$. amentacea and $D$. polypodioides were collected once in winter, spring, summer and autumn to follow the seasonal variation in total phenolic content (TPC). In each season undamaged thalli of the same size and length were collected with a hammer and chisel, at sunrise. After collection, thalli were placed in plastic bags filled with seawater, for transportation within $1 \mathrm{~h}$ to the wet laboratory at the University of Palermo. 


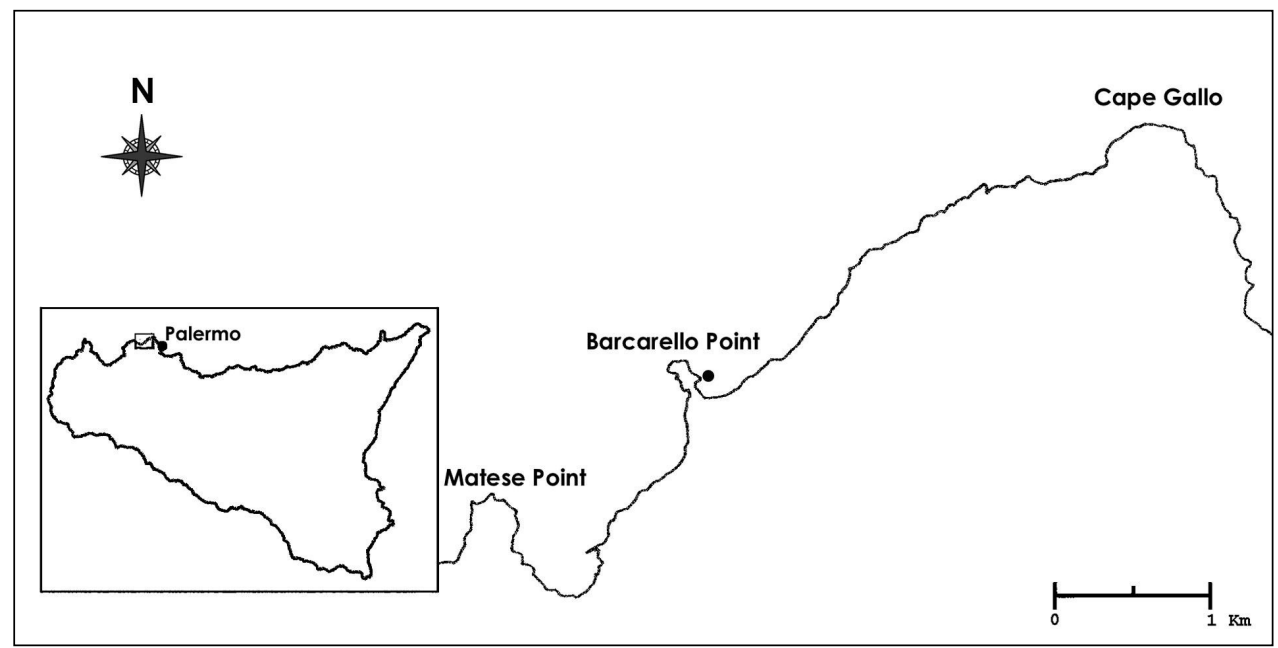

Fig. 1. Location of the study area.

In the laboratory, thalli were gently washed with demineralised water and their epiphytes were removed. Then, thalli were identified with the aid of a stereo microscope and analytical keys (Amico \& al. 1985; Gómez Garreta \& al. 2000; Cormaci \& al. 2012).

Air temperature, solar radiation and precipitation near the sampling location were obtained from SIAS (Servizio Informativo Agrometerologico Siciliano; Fig. 2) whereas water temperature was measured during sampling.

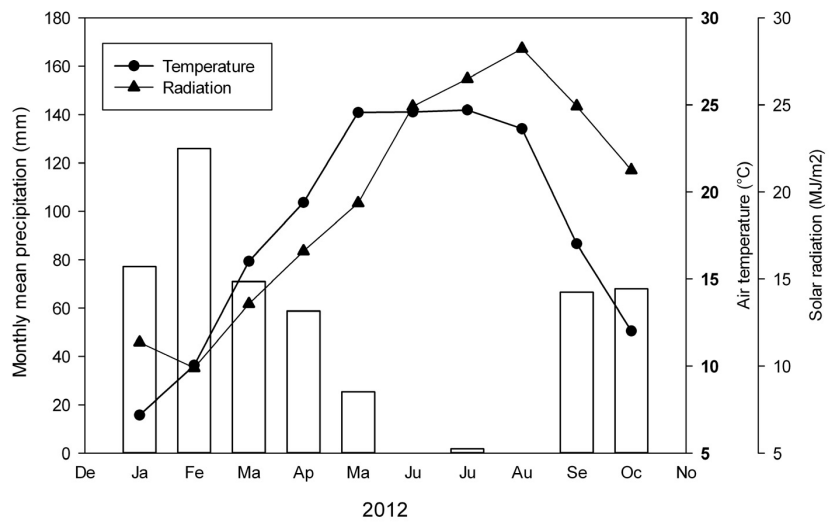

Fig. 2. Seasonal fluctuation of the mean air temperature $\left({ }^{\circ} \mathrm{C}\right)(\bullet)$, the mean solar radiation per day $(\mathrm{MJ} / \mathrm{mq})(\boldsymbol{\Lambda})$ and the mean precipitation per day (bars). 


\section{Determination of total phenolic content}

For the determination of TPC, thalli $(n=5)$ were washed with demineralised water and oven-dried at $50{ }^{\circ} \mathrm{C}$ for $48 \mathrm{~h}$. The whole thalli were chopped into fragments and then pulverised with mortar and pestle. A mixed sub-sample of $2 \mathrm{~g}$ (dry weight, DW) for each sample was extracted with $25 \mathrm{ml}$ of $96 \%(\mathrm{v} / \mathrm{v})$ ethanol in centrifuge tubes in a $37{ }^{\circ} \mathrm{C}$ water bath for $2.5 \mathrm{~h}$ (Zahra \& al. 2007 modified). The mixture was centrifuged at $2200 \mathrm{~g}$ for 10 min and the supernatant was collected.

TPC was determined colorimetrically with the Folin-Ciocalteu reagent (Sigma-Aldrich Chemie, Steinheim, Germany), using phloroglucinol as the reference standard (Folin \& Ciocalteu 1927; Kuda \& al. 2005). The Folin-Ciocalteu method was chosen because it provides more consistent results and is less affected by interfering non-phenolic compounds than other colorimetric methods (Singleton \& Rossi 1965; Waterman \& Mole 1994; Van Alstyne 1995; Kamiya \& al. 2010).

Briefly, $0.4 \mathrm{ml}$ of the ethanol extract were transferred into a test tube containing $0.8 \mathrm{ml}$ of the $10 \%$ Folin-Ciocalteu-phenol reagent. After $3 \mathrm{~min}, 1.6 \mathrm{ml}$ of a $10 \%$ sodium carbonate solution was added. The contents of the tube was mixed thoroughly using a glass rod and left to stand at room temperature for $1 \mathrm{~h}$. After the reaction, the absorbance of the samples was measured with a spectrophotometer (DU 800, Beckman Coulter Inc., Fullerton, CA, USA) at $750 \mathrm{~nm}$. TPC was expressed as phloroglucinol equivalents in percentage of dry weight (\% DW).

\section{Statistical analysis}

All analyses were run in duplicate, and results are presented as mean values \pm standard deviation (SD). Statistical analysis was carried out using SigmaPlot 12 software (Systat Software, Inc., San Jose, USA). Linear regression was used to analyse the correlation between environmental variables and TPC $(p<0.05)$.

The significance of differences in TPC of C. amentacea and D. polypodioides as a function of season was tested with a one-way ANOVA. Tukey's post hoc tests were performed when data showed significant differences $(p<0.05)$.

\section{Results}

In winter, spring and autumn, the total phenol content of $D$. polypodioides was significantly higher $(p<0.05)$ than in $C$. amentacea, while in summer the TPC of the two species was comparable (Table 1). Both species showed a seasonal pattern of total phenolic contents and differences in the period of their maximum production were also observed between the two species (Fig. 3-4). In D. polypodioides the highest levels in TPC were observed during winter and autumn $(0.95 \pm 0.18$ and $0.81 \pm 0.07 \%$ of $\mathrm{DW}$, respectively) whereas in $C$. amentacea they occurred during spring and summer $(0.17 \pm 0.01$ and $0.57 \pm 0.15 \%$ of $\mathrm{DW}$, respectively).

A significant increase of TPC occurred between spring and summer in C. amentacea (Fig. 3, Table 1). In D. polypodioides the decrease between winter and spring and the increase from summer to autumn were both significant (Fig. 4, Table 1).

In $D$. polypodioides the TPC showed a significant negative correlation both with sea- 
Table 1. Results of the one-way ANOVA on TPC content of Cystoseira amentacea and Dictyopteris polypodioides collected in winter, spring, summer and autumn.

\begin{tabular}{|l|c|c|c|c|c|}
\hline Source of variation & SS & df & MS & F & p \\
\hline Between groups & 3.675 & 7 & 0.525 & 53.201 & $<0.001$ \\
\hline Residual & 0.316 & 32 & 0.00987 & & \\
\hline Total & 3.991 & 39 & & & \\
\hline
\end{tabular}

water temperature $\left(\mathrm{R}^{2}=0.67, p<0.001\right.$; data not shown) and medium solar radiation $\left(\mathrm{R}^{2}=0.96, p<0.001\right.$; data not shown). Instead, in $C$. amentacea the correlation was positive both with seawater temperature $\left(\mathrm{R}^{2}=0.75, p<0.001\right.$; Fig. 5$)$ and medium solar radiation $\left(\mathrm{R}^{2}=0.49, p<0.001\right.$; Fig. 6).

\section{Discussion}

In both species a distinct seasonal fluctuation of TPC was observed but the pattern was different. This result was in agreement with previous studies that report for brown algae a seasonal pattern of TPC, with maximum levels occurring in different seasons (Steinberg 1995; Connan 2004; Stiger \& al. 2004; Abdala-Díaz \& al. 2006; Zubia \& al. 2008; Kamiya $\&$ al. 2010). For example, Fucales exhibited maximal phenolic levels in summer (Connan 2004; Abdala-Díaz \& al. 2006), in winter (Ragan \& Jensen 1978) or from late summer to the middle winter (Ragan \& Glombitza 1986). Seasonal variations in TPC have been gen-

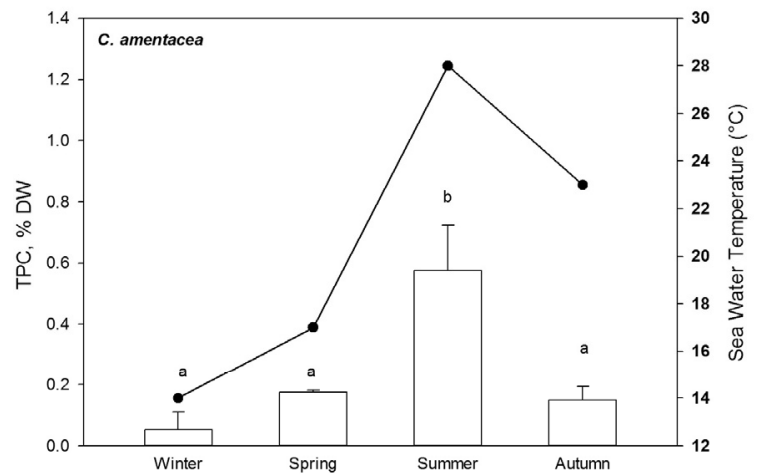

Fig. 3. Cystoseira amentacea: seasonal variations of TPC and sea water temperature. Bars represent mean \pm standard deviation $(n=5)$; letters indicate significant differences (One-way ANOVA, Tukey's test, $\mathrm{p}<0.001)$. 


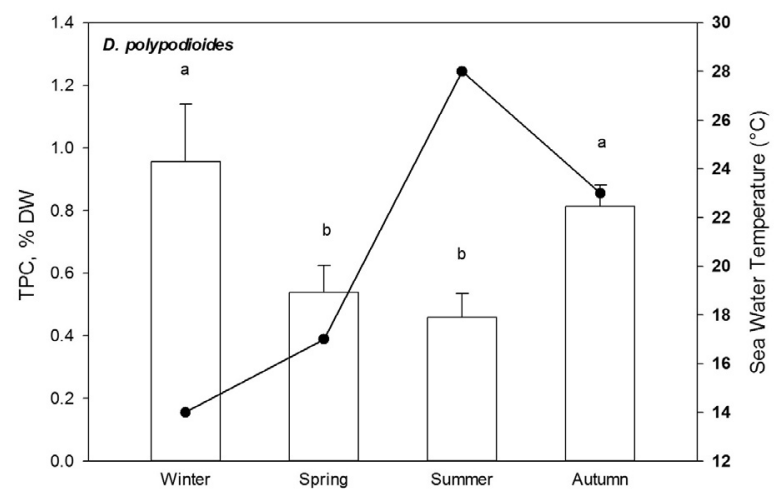

Fig. 4. Dictyopteris polypodioides: seasonal variations of TPC and sea water temperature. Bars represent mean \pm standard deviation $(\mathrm{n}=5)$; letters indicate significant differences (One-way ANOVA, Tukey's test, $p<0.001$ ) (One-way ANOVA, Tukey's test, $\mathrm{p}<0.001$ ).

erally related to different abiotic factors such as temperature, irradiance levels and salinity but also to the reproductive state of the algae (Ragan \& Jensen 1978; Pedersen 1984; Pavia \& al. 1997; Connan \& al. 2004).

The two species examined in this study are both semi-perennant but with different life-cycle. In C. amentacea adult thalli, consisting of main axes with numerous primary branches covered by many leaf-like structures, are present in summer. Instead, adult

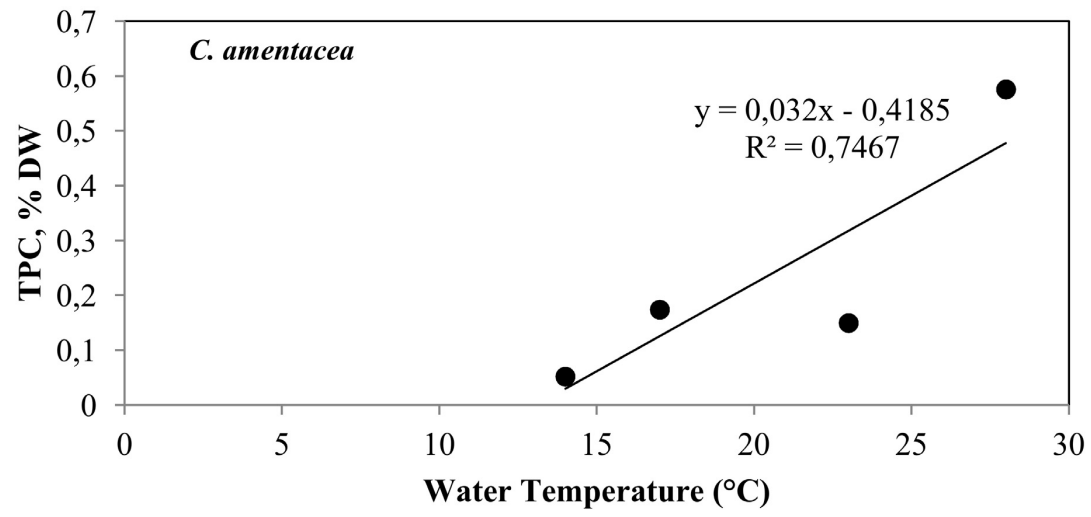

Fig. 5. Cystoseira amentacea: correlation between TPC and seawater temperature. 


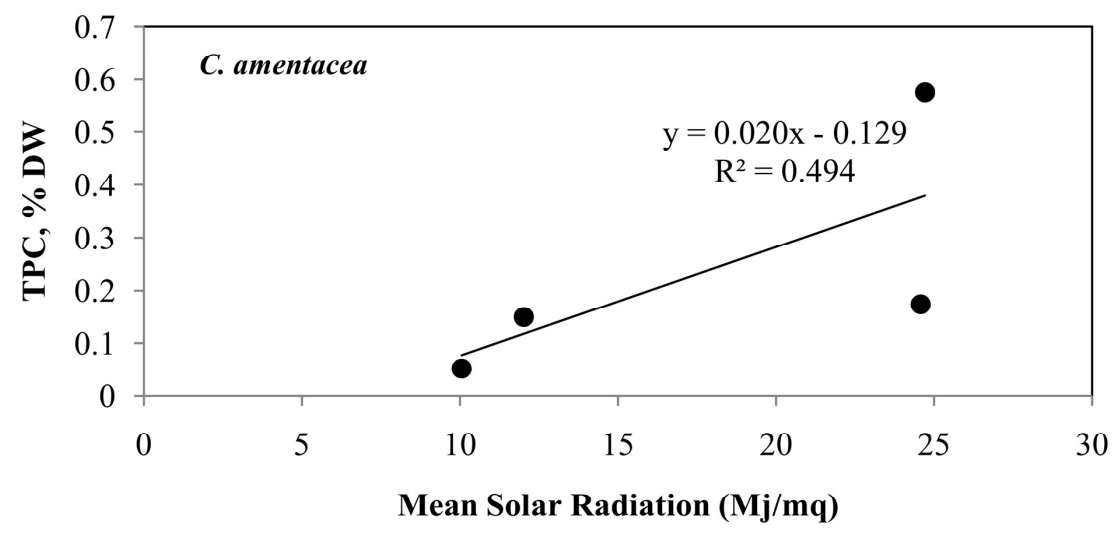

Fig. 6. Cystoseira amentacea: correlation between TPC and mean solar radiation.

thalli of $D$. polypodioides, consisting of a sheet-like frond with an evident mid-rib, are generally present in the autumn-spring period.

Our results are consistent with the hypothesis of variations in TPC levels through the year in accordance with different stages of the life-cycle (Van Alstyne \& al. 2001), with higher TPC values in more palatable stages.

C. amentacea showed the lowest value of TPC in winter when only the main axes, the less palatable parts of the thallus, are present. In spring, when new branches are sprouted, a significant increase of TPC was observed. The young branches, more vulnerable than axes, preferentially would allocate resources towards chemical defences (Schoenwaelder 2002; Swanson \& Druehl 2002; Kamiya \& al. 2010). The TPC levels reached the highest value in summer, when long primary branches with numerous leaf-like structures are present. These results are also in line with the observed positive correlation between TPC and solar radiation reported in several studies (Yates \& Peckol 1993; Peckol \& al. 1996; Connan \& al. 2004; Stiger \& al. 2004; Kamiya \& al. 2010).

Also for $D$. polypodioides the fluctuations of TPC were concordant with the phenology of the alga. The lowest levels of TPC were observed in summer, the resting season, when only the less palatable parts of the thallus are present, the mid-rib together with the remains of the frond. Also in this case, the negative correlation between TPC and water temperature could reflect the phenology of this species.

Therefore, the phenolic content would reach the highest levels in the more palatable parts of the thallus: the branches (both the newly sprouted ones and the longest ones bearing receptacles) in C. amentacea and the sheet-like frond in D. polypodioides.

Our findings are in agreement with Van Alstyne \& al. (1999) who found in Fucales an intra-thallus distribution of phenolic compounds, usually more concentrated in the meristematic zones, i.e., the distal extremities. However, Pavia \& al. (2002) observed in Ascophyllum nodosum (Linnaeus) Le Jolis a decrease in the phenolic levels proceeding from the stipe towards ramifications and receptacles. 
Differences in the absolute levels of phenolic contents have been previously observed among brown algae (e.g. Ragan \& Glombitza 1986; Van Alstyne \& al. 1999; Connan \& al. 2004; Abdala-Díaz \& al. 2006; Plouguerné \& al. 2006; Kamiya \& al. 2010; Le Lann \& al. 2012), partly due to the methods used both in sample preparation (Le Lann \& al. 2008) and phenol extraction, since different solvents vary in their extraction efficiency (Waterman \& Mole 1994; Koivikko \& al. 2005; Koivikko 2008).

As the same method has been used to analyse the TPC in the two species, the significant differences in TPC observed might reflect differences in herbivore pressure that in turn may vary in relation to differences in bathymetric level and/or thallus morphology. Indeeed, $C$. amentacea, inhabiting the infralittoral fringe, experiences regular emersion even if the apical parts of the thalli may remain uncovered only for very short periods, whereas $D$. polypodioides, living in the upper infralittoral zone, is continually submerged.

The emersion of thalli, even if it is incomplete, imply a direct exposure to solar radiation that gradually decreases as it passes through seawater (Calkins \& Thordardottir 1980; Shick \& al. 1996) and secondary metabolites production is directly related to the quantity and quality of irradiance (Peckol \& al. 1996; Pavia \& Brock 2000; Pavia \& Toth 2000; Henry \& Van Alstyne 2004). As emersion phases may affect phenolic compounds production in relation to intensity of solar radiation, we would expect a higher phenolic content in algae inhabiting the infralittoral fringe as compared with those settled in the constantly submerged zones. For example, Pavia \& Brock (2000) found phenol levels higher in thalli alternately emerged and immersed than in those of continually immersed thalli.

Our findings however, do not confirm these observations, but agree with Connan $\&$ al. (2004) who, analyzing the phenolic contents in brown algae forming belts in the northern coast of Brittany (France), found higher TPC in species growing at mid-tide level compared to that of species inhabiting either the low-tide level or the upper mid-littoral fringe. Thus the light stressing condition of the emersion phases does not necessarily result in an increase of TPC. To explain that, Connan \& al. (2004) hypothesized that mechanisms of photo-protection other than phenol production exist in seaweeds.

Differences in bathymetric level also imply differences in water movement that may have direct effects on herbivore pressure. Consumer pressure is generally lowest in wave exposed shores where the feeding ability of most mobile consumers is limited to calm periods (Witman \& Dayton 2001). Therefore, in the infralittoral fringe a water movement higher than in the constantly submerged zones would make feeding on algae more difficult. Differences in TPC found between $C$. amentacea and D. polypodioides are consistent with these observations.

Besides bathymetric level, herbivore pressure may vary also in relation to thallus morphology. Sheet algae, resulting more palatable than leathery or crustose ones (Littler \& Littler 1980; Steneck \& Dethier 1994), are expected to produce a higher phenolic content. These observations are in agreement with our finding of a higher phenolic content in $D$. polypodioides than in C. amentacea.

In this study, we found further evidence that the life-cycle, thallus morphology and bathymetric level influence TPC in brown algae. The distinct seasonal trend showed that phenolic metabolism of these species was significantly correlated with the growth cycle that is in turn strictly dependent on temperature. However, it is worth noting that the plasticity of phenolic concentration due to fluctuation in abiotic factors makes it more difficult 
to detect the phenolic change during the algal life cycle. Therefore, seasonal variation of TPC should be analysed taking in consideration all environmental factors.

The interspecific variations of phenolic content observed between $C$. amentacea and $D$. polypodioides might result from a combination of external (biotic and abiotic) and internal (morphological) factors.

Despite the numerous studies dedicated to variation of phenolic content in brown algae, a great variation has been observed in relation to external as well as intrinsic factors, that could act, alone or in combination, inducing qualitative and quantitative variations intraindividual, among individuals and inter-species.

Thus additional long-term studies are needed for a better understanding of the variation in TPC in brown algae. More extensive studies need to be carried out, for example, in assessing the relationship with stages of life cycle and environmental factors; the intrathallus, inter-individuals and inter-specific differences in constitutive TPC (functioning independently of stress conditions); the qualitative variation of phenol compounds in order to better understand the role of single components in defense mechanisms.

\section{References}

Abdala-Díaz, R. T., Cabello-Pasini, A., Pérez-Rodríguez, E., Conde Álvarez, R. M. \& Figueroa, F. L. 2006: Daily and seasonal variations of optimum quantum yield and phenolic compounds in Cystoseira tamariscifolia (Phaeophyta). - Mar. Biol. 148: 459-465.

Al-sane, K. O., Povero, G. \& Perata, P. 2011: Anthocyanin tomato mutants: Overview and characterization of an anthocyanin-less somaclonal mutant. - Pl. Biosyst. 145: 436-444. doi: $10.1080 / 11263504.2010 .548914$

Amico, V., Giaccone, G., Colombo, P., Colonna, P., Mannino, A.M. \& Randazzo, R. 1985: Un nuovo approccio allo studio della sistematica del genere Cystoseira C. Agardh. - Boll. Acc. Gioenia Sci. Nat. 18(326): 887-986.

Amsler, C. D. 2008: Algal sensory chemical ecology. - Pp. 297-309 in: Amsler, C. D. (ed). Algal Chemical Ecology. - Berlin \& Heidelberg.

— \& Fairhead, V. A. 2006: Defensive and sensory chemical ecology of brown algae. - Adv. Bot. Res. 43: 1-91.

Arnold, T. M., Tanner, C. E. \& Hatch, W. I. 1995: Phenotypic variation in polyphenolic content of the tropical brown alga Lobophora variegaae as a function of nitrogen availability. - Mar. Ecol. Prog. Ser. 123: 177-183.

Ballesteros, E. \& Romero, J. 1988: Zonation patterns in tideless environments (Northwestern Mediterranean): looking for discontinuities in species distributions. - Inv. Pesq. 52: 593-614.

Calkins, J. \& Thordardottir, T. 1980: The ecological significance of solar UV radiation on aquatic organisms. - Nature 283: 563-566.

Connan, S. 2004: Étude de la diversité spécifique des macroalgues de la Pointe de Bretagne et analyse des composés phenoliques des Phéophycées dominantes. - PhD Thesis, University of West Brittany.

—, Goulard, F., Stiger, V., Deslandes, E. \& Ar Gall, E. 2004: Phlorotannins in belt-forming brown algae of a sheltered shore. - Bot. Mar. 47: 410-416.

Conover, J. T. \& Sieburth, J. M. 1964: Effects of Sargassum distribution on the epibiota and its antibacterial activity. - Bot. Mar. 6: 147-157.

Cormaci, M., Furnari, G., Catra, M., Alongi, G. \& Giaccone, G. 2012: Flora marina bentonica del Mediterraneo: Phaeophyceae. - Boll. Acc. Gioenia Sci. Nat. 45(375): 1-508. 
Feldmann, J. 1937: Recherches sur la végétation marine de la Méditerranée. La côte des Albères. Rev. Algol. 10: 1-339.

Folin, O. \& Ciocalteu, V. 1927: On tyrosine and tryptophane determinations in proteins. - J. Biol. Chem. 12: 239-243.

Gómez Garreta, A., Barcelo Martí, M. C., Ribera Siguan, M. A. \& Rull Lluch, J. 2000: Cystoseira C. Agardh. - Pp. 99-166 in: Gómez Garreta, A. (ed). Flora Phycologica Iberica, 1. - Murcia.

Hay, M. E. 1996: Marine chemical ecology: what's known and what's next? - J. Exp. Mar. Biol. Ecol. 200: 103-134.

- \& Fenical, W. 1988: Marine plant-herbivore interactions: the ecology of chemical defense. Annu. Rev. Ecol. Syst. 19: 111-145.

Henry, B. E. \& Van Alstyne, K. L. 2004: Effects of UV radiations on growth and Phlorotannins in Fucus gardneri (Phaeophyceae) juveniles and embryos. - J. Phycol. 40: 527-533.

Jormalainen, V. \& Honkanen, T. 2008: Macroalgal chemical defenses and their roles in structuring temperate marine communities. - Pp. 57-89 in: Amsler, C. D. (ed). Algal chemical ecology. - Berlin.

Kamiya, M., Nishio, T., Yokoyama, A., Yatsuya, K., Nishigaki, T., Yoshikawa, S. \& Onki, K. 2010: Seasonal variation of phlorotannin in sargassacean species from the coast of the Sea of Japan. - Phycol. Res. 58: 53-61.

Koivikko, R. 2008: Variation of phlorotannins among three population of Fucus vesiculosus as revealed by HPLC and colorimetric quantification. - J. Chem. Ecol. 34: 57-64.

-, Loponen, J., Honkanen, T., Jormalainen, V. 2005: Contents of soluble, cell-wall-bound and exuded phlorotannins in the brown alga Fucus vesiculosus, with implications on their ecological functions. - J. Chem. Ecol. 31: 195-212.

Kremer, D., Stabentheiner, E., Jurišić Grubešić, R., Oberländer, A., Vladimir-Knežević, S., Kosalec, I. \& Ballian, D. 2012: A morphological and chemotaxonomic study of Teucrium arduini L. in Croatia, and Bosnia and Herzegovina. - Pl. Biosyst. 146: 402-412. doi: 10.1080/11263504.2011.557098

Kuda, T., Tsunekawa, M., Hishi, T. \& Araki, Y. 2005: Antioxidant properties of dried kayamo-nori, a brown alga Scytosiphon lomentaria (Scytosiphonales, Phaeophyceae). - Food Chem. 89: 617-622.

Lee, R. E. 2008: Phycology, $4^{\circ}$ ed. - Cambridge.-

Le Lann, K., Jégou, C. \& Stiger-Pouvreau, V. 2008: Effect of different conditioning treatments on total phenolic content and antioxidant activities in two Sargassacean species: Comparison of the frondose Sargassum muticum (Yendo) Fensholt and the cylindrical Bifurcaria bifurcata R. Ross. - Phycol. Res. 56: 238-245.

-, Connan, S. \& Stiger-Pouvreau, V. 2012: Phenology, TPC and size-fractioning phenolics variability in temperate Sargassaceae (Phaeophyceae, Fucales) from Western Brittany: Native versus introduced species. - Mar. Environ. Res. 80: 1-11.

Littler, M. M. \& Littler, D. S. 1980: The evolution of thallus form and survival strategies in benthic marine macroalgae: field and laboratory tests of a functional form model. - Am. Nat. 116: 25-44.

Lobban, C. S. \& Harrison, P. J. 1994: Seaweed Ecology and Physiology. - Cambridge.

Lopes, G., Sousa, C., Silva, L. R., Pinto, E., Andrade, P. B., Bernando, J., Mouga, T. \& Valentão, P. 2012: Can phlorotannins purified extracts constitute a novel pharmacological alternative for microbial infections with associated inflammatory conditions? - PLoS One 7(2): e31145. doi:10.1371/journal.pone. 0031145

Lüning, K. 1990: Seaweeds. Their environment, biogeography and ecophysiology. - New York.

Martinelli, F. \& Tonutti, P. 2012: Flavonoid metabolism and gene expression in developing olive (Olea europaea L.) fruit. - Pl. Biosyst. 146: 164-170. doi: 10.1080/11263504.2012.681320

Paul, V. J., Ritson-Williams, R. \& Sharp, K. 2011: Marine chemical ecology in benthic environments. - Nat. Prod. Rep. 28: 345-387. 
Pavia, H. \& Brock, E. 2000: Extrinsic factors influencing phlorotannin production in the brown alga Ascophyllum nodosum. - Mar. Ecol. Prog. Ser. 193: 285-294.

— \& Toth, G. 2000: Influence of light and nitrogen on the phlorotannin content of the brown seaweed Ascophyllum nodosum and Fucus vesiculosus. - Hydrobiologia 440: 299-305.

—, — \& Åberg, P. 2002: Optimal defense theory: elasticity analysis as a tool to predict intraplant variation in defenses. - Ecology 83: 891-897.

—, Cervin, G., Lindgren, A. \& Åberg, P. 1997: Effects of UVB radiation and simulated herbivory on phlorotannins in the brown alga Ascophyllum nodosum. - Mar. Ecol. Prog. Ser. 157: 139-146.

Peckol, P., Krane, J. M. \& Yates, J. L. 1996: Interactive effects of inducible defense and resource availability on phlorotannins in the North Atlantic brown alga Fucus vesiculosus. - Mar. Ecol. Prog. Ser. 138: 209-217.

Pedersen, A. 1984: Studies on phenol content and heavy metal uptake in fucoids. - Hydrobiologia 116/117: 498-504.

Plouguerné, E., Le Lann, K., Connan, S., Jechoux, G., Deslandes, E. \& Stiger-Pouvreau, V. 2006: Spatial and seasonal variation in density, reproductive status, length and phenolic content of the invasive brown macroalga Sargassum muticum (Yendo) Fensholt along the coast of Western Brittany (France). - Aquat. Bot. 85: 339-346.

Potin, P., Bouarab, K., Salaün, J.-P., Pohnert, G. \& Kloareg, B. 2002: Biotic interactions of marine algae. - Curr. Opin. P1. Biol. 5: 308-317.

Ragan, M. A. \& Glombitza, K. W. 1986: Phlorotannins, brown alga polyphenols. - Prog. Phycol. Res. 4: 129-241.

— \& Jensen, A. 1978: Quantitative studies on brown algal phenols. II. Seasonal variation in polyphenols content of Ascophyllum nodosum (L.) Le Jol. and Fucus vesiculosus L. - J. Exp. Mar. Biol. Ecol. 34: 245-258.

Schoenwaelder, M. E. A. 2002: Physode distribution and the effect of thallus sunburn in Hormosira banksii (Fucales, Phaeophyceae). - Bot. Mar. 45: 262-266.

- \& Wiencke, C. 2000: Phenolic compounds in the embryo development of several northern hemisphere fucoids. - Pl. Biol. 2: 24-33.

Shick, J. M., Lesser, M. P. \& Jokiel, P. L. 1996: Effects of ultraviolet radiation on corals and other coral reef organisms. - Glob. Change Biol. 2: 527-545.

Singleton, V. L. \& Rossi, J. A. Jr. 1965: Colorimetry of total phenolic with phosphomolybdic-phosphotungstic acid reagents. - Amer. J. Enol. Viticult. 16: 144-158.

Steinberg, P. D. 1995: Seasonal variation in the relationship between growth rate and phlorotannin production in the kelp Ecklonia radiata. - Oecologia 102: 169-173.

Steneck, R. S. \& Dethier, M. N. 1994: A functional group approach to the structure of algal-dominated communities. - Oikos 69: 476-498.

Stiger, V., Deslandes, E. \& Payri, C. E. 2004: Phenolic contents of two brown algae Turbinaria ornata and Sargassum mangarevense on Tahiti (French Polynesia): interspecific, ontogenic and spatio-temporal variations. - Bot. Mar. 47: 402-409.

Sudatti, D. B., Fujii, M. T., Rodigues, S. V., Turra, A. \& Pereira, R. C. 2011: Effect of abiotic factors on growth and chemical defense content in Laurencia dendroidea J. Agardh (Ceramiales, Rhodophyta) cultivated clones. - Mar. Biol. 158: 1439-1446.

Swanson, A. K. \& Druehl, L. 2002: Induction, exudation and the UV protective role of kelp phlorotannins. - Aquat. Bot. 73: 241-253.

Tahi, H., Wahbi, S., El Modafar, C., Aganchich, A. \& Serraj, R. 2008: Changes in antioxidant activities and phenol content in tomato plants subjected to partial root drying and regulated deficit irrigation. - Pl. Biosyst. 142: 550-562. doi: 10.1080/11263500802410900

Targett, N. M. \& Arnold, T. M. 2001: Effects of secondary metabolites on digestion in marine herbivores. - Pp. 391-411 in: McClintock, J. B. \& Baker, B.J. (eds). Marine Chemical Ecology. - Florida. 
—, Boettcher, A. A., Targett, T. E. \& Vrolijk, N. H. 1995: Tropical marine herbivore assimilation of phenolic-rich plants. - Oecologia 103: 170-179.

Tuomi, J., Ilvessalo, H., Niemelã, P., Sirén, S. \& Jormalainen, V. 1989: Within-plant variation in phenolic content and toughness of the brown alga Fucus vesiculosus L. - Bot. Mar. 32: 505-509.

Van Alstyne, K. L. 1995: A comparison of three methods for quantifying algal polyphenolic compounds. - J. Chem. Ecol. 21: 45-58.

— \& Paul, V. J. 1990: The Biogeography of polyphelonic compounds in marine macroalgae: temperate brown algal defenses deter feeding by tropical herbivorous fishes. - Oceanologia 84: 158-163.

-, Whitman, S. L. \& Ehlig, J. M. 2001: Differences in herbivore preferences, phlorotannin production, and nutritional quality between juvenile and adult tissues from marine brown algae. Mar. Biol. 139: 201-210.

—, Mccarthy, III J. J., Hustead, C. L. \& Kearns, L. J. 1999: Phlorotannin allocation among tissues of northeastern pacific kelps and rockweeds. - J. Phycol. 35: 482-492.

Waterman, P. G. \& Mole, S. 1994: Analysis oh Phenolic Plant Metabolities. - Oxford.

Witman, J. D. \& Dayton, P. K. 2001: Rocky subtidal communities. - Pp. 339-366 in: Bertness, M. D., Gaines, S. D. \& Hay, M. E. (eds). Marine community ecology. -Sunderland, USA.

Yates, J. L. \& Peckol, P. 1993: Effects of nutrient availability and herbivory on polyphenolics in the seaweed Fucus vesiculosus. - Ecology 74: 1757-1766.

Zahra, R., Mehrnaz, M., Farzaneh, V. \& Kohzad, S. 2007: Antioxidant activity of exctract from a brown alga, Sargassum boveanum. - Afr. J. Biotechnol. 6: 2740-2745.

Zubia, M., Payri, C. \& Deslandes, E. 2008: Alginate, mannitol, phenolic compounds and biological activities of two range-extending brown algae, Sargassum mangarevense and Turbinaria ornata (Phaeophyta: Fucales), from Tahiti (French Polynesia). - J. Appl. Phycol. 20: 1033-1043.

Address of the authors:

Anna Maria Mannino, Valentina Vaglica \& Elisabetta Oddo,

Dipartimento di Scienze e Tecnologie Biologiche Chimiche e Farmaceutiche, Via Archirafi 38, 90123 Palermo, Italy. E-mail: annamaria.mannino@unipa.it 